\title{
KARAKTERISTIK PENDIDIHAN DALAM CELAH SEMPIT REKTANGULAR VERTIKAL DENGAN VARIASI TEMPERATUR AWAL PLAT
}

\author{
IGN. Bagus Catrawedarma ${ }^{1}$, Indarto ${ }^{2}$, Mulya Juarsa ${ }^{3}$ \\ ${ }^{(1)}$ Program Studi Teknik Mesin, Politeknik Negeri Banyuwangi, Banyuwangi \\ (2) Jurusan Teknik Mesin dan Industri, Fakultas Teknik, Universitas Gadjah Mada, \\ Yogyakarta \\ (3)PTRKN BATAN, Gd. 80 Kawasan PUSPIPTEK Serpong, Tangerang \\ Email:ngurahcatra@yahoo.com
}

\begin{abstract}
ABSTRAK
Analisis perpindahan kalor pendidihan untuk mengetahui pengaruh temperatur awal plat utama terhadap karakteristik pendidihan yang meliputi waktu rewetting, pola rewetting, fluks kalor, serta Critical Heat Flux (CHF) telah dipelajari berdasarkan kurva pendidihan dan fluks kalor yang dihitung dari transien temperatur permukaan plat, yang merupakan hasil eksperimen dengan menggunakan 2 plat vertikal dengan celah sempit antar plat utama dan penutup adalah $1 \mathrm{~mm}$. Debit dan temperatur air pendingin ditetapkan sebesar 0,09 lt/detik dan temperatur saturasi. Temperatur awal plat utama divariasikan dari $500^{\circ} \mathrm{C}, 550^{\circ} \mathrm{C}$, dan $600^{\circ} \mathrm{C}$. Hasil analisis menunjukkan bahwa waktu rewetting terendah sebesar 30 sekon dan tertinggi sebesar 290 sekon. CHF tertinggi sebesar $750 \mathrm{~kW} / \mathrm{m}^{2}$ dan terendah sebesar $400 \mathrm{~kW} / \mathrm{m}^{2}$. Semakin tinggi temperatur awal plat, maka semakin lama waktu rewettingnya. Perubahan temperatur awal plat utama tidak mempengaruhi pola rewetting. Semakin tinggi temperatur awal plat, maka nilai CHF-nya semakin rendah. Daerah didih film tidak sesuai dengan kasus pool boiling. Pada daerah transisi, semakin rendah temperatur awal plat, maka semakin mendekati korelasi Murase. Nilai CHF mendekati korelasi Leinhard. Titik Leidenfrost sesuai dengan korelasi Zuber. Daerah didih inti mendekati korelasi Murase untuk superheat vapor.
\end{abstract}

Kata kunci: waktu rewetting, pola rewetting, fluks kalor, $\mathrm{CHF}$

\begin{abstract}
The analyzise of boiling heat transfer for knowing the effect of startup temperature of main plate to the boiling characteristics including rewetting time, rewetting, heat flux, and Critical Heat Flux (CHF) is studied based on boiling curve and heat flux which are calculated from transient surface plate temperature. It is the result from experimental study using two vertical plates with $1 \mathrm{~mm}$ narrow split between main plate and its closing lid. The used water flowrate and temperature are 0.09 $1 / \mathrm{s}$ and saturated temperature respectivelly. The startup temperatures of the main plate are variated from $500^{\circ} \mathrm{C}, 550^{\circ} \mathrm{C}$, and $600^{\circ} \mathrm{C}$. The result shows that the lowest rewetting time is 30 second and the highest is 290 second. The highest and the lowest CHF values are $750 \mathrm{~kW} / \mathrm{m}^{2}$ and $400 \mathrm{~kW} / \mathrm{m}^{2}$ respectivelly. As the startup temperatures of the main plate increases, the rewetting time also increases. The change of startup temperatures of the main plate does not effect the rewetting. The
\end{abstract}


result also shows that adding the startup temperatures of the main plate will deplete CHF value. It also give result that boiling film area does not has correlation with pool boiling. On transition area, decreasing startup temperatures of the main plate will make it close to Murase corelation and it also shows the same corelation for superheat vapor main boiling area. Moreover, the CHF value is close to Leinhard corelation and Leidenfrost point is equal to Zuber corelation.

Keywords: Rewetting time, rewetting, heat flux, CHF

\section{PENDAHULUAN}

Pendidihan (boiling heat transfer) merupakan fenomena yang kompleks dan penting. Disebut fenomena kompleks karena dalam prosesnya terjadi perpindahan kalor 2 fase dengan berbagai parameter yang berpengaruh. Dikatakan penting karena terkait dengan aplikasinya dalam menentukan performansi heat exchanger dan keselamatan reaktor nuklir. Fenomena boiling heat transfer dalam reaktor nuklir terjadi saat kasus pendinginan pada celah sempit yang terbentuk antara lelehan teras (debris) dengan dinding reaktor saat terjadinya kecelakaan parah (severe accident) di reaktor Three Mile Island Unit 2 (TMI-2). Oleh karena itu, perlu pemahaman yang lebih mendalam terkait dengan karakteristik boiling heat transfer dalam celah sempit.

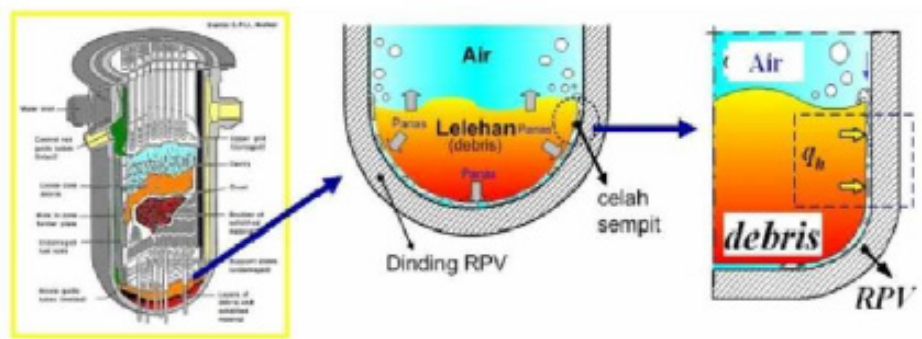

Gambar 1. Terbentuknya celah sempit dalam reaktor [3]

Banyak penelitian terkait dengan boiling heat transfer dalam celah sempit telah dilakukan oleh para peneliti, yang memfokuskan pada beberapa parameter seperti, critical heat flux (CHF), pressure drop, dan pola aliran yang terjadi pada celah sempit berdasarkan variasi ukuran celah, fluida kerja, dan panjang plat yang dipanaskan (heated length). Sudo dan Kaminaga (1989) [9] melakukan penelitian pada celah sempit rektangular vertikal dengan air sebagai fluida uji untuk kasus pemanasan dari dua sisi (double heating), yang menggunakan ukuran panjang $750 \mathrm{~mm}$, lebar $50 \mathrm{~mm}$, dan lebar celah 2,25 mm serta panjang $375 \mathrm{~mm}$, lebar $50 \mathrm{~mm}$, dan lebar celah 2,80 mm. Penelitian ini dilakukan untuk mendapatkan karakteristik CHF dengan membandingkan prediksi berdasarkan korelasi CCFL (Counter Current Flow Limitation) dan CHF hasil eksperimen. Hasil penelitiannya mengindikasikan bahwa aspek rasio mempunyai peran yang penting terhadap karakteristik CCFL dan CHF untuk aliran berlawanan arah dan aspek rasio berimplikasi kuat bahwa CHF untuk aliran ke bawah adalah minimum dalam kondisi flooding pada kasus inlet yang besar dan juga ketika inlet fluks massa air lebih besar dari pada dalam kondisi flooding untuk kasus inlet air yang kecil.

Chang dan Stan (1993) [2] melakukan penelitian dengan menggunakan aluminium rektangular vertikal yang dipanaskan dari satu sisi, dengan lebar celah $1,98 \mathrm{~mm}$, lebar 50,8 $\mathrm{mm}$, dan panjangnya 609,6 mm. Penelitian dilakukan dalam kondisi steady state, kondisi 
aliran dan tekanan yang rendah untuk konveksi alami. Hasil penelitiannya mengindikasikan bahwa CHF yang didapat tidak sesuai dengan korelasi yang ada yang dikembangkan untuk kondisi aliran dan tekanan yang rendah. Korelasi ini terbatas untuk tekanan atmosfer, tidak ada data yang tersedia untuk tekanan subatmosfer, yang merupakan parameter penting untuk CHF konveksi alami. Aliran ke bawah menghasilkan nilai CHF $15 \%$ lebih kecil dari aliran ke atas, pengaruh subcooling untuk yang kurang dari $44 \mathrm{~K}$ tidak signifikan dalam celah sempit rektangular, jika subcooling meningkat sampai $66 \mathrm{~K}$, maka CHF meningkat 15\%. Kemudian Xia, dkk. (1996) [10] melakukan penelitian fenomena pendidihan konveksi alamiah menggunakan fluida freon R-113 pada celah sempit vertikal. Fluks massa pada masukan dari bawah telah diukur, diperoleh bahwa terjadi pengurangan fluks massa yang disebabkan oleh percepatan kehilangan tekanan yang diamati sebelum tercapainya CHF. Pengurangan ukuran celah dan menaikkan ukuran panjang pelat pada fluks massa yang rendah dilakukan untuk memulai pengurangan masukan fluks massa.

Peng dan Wang (1998) [7] melakukan analisis dalam rektangular stainless steel plat dengan metanol sebagai fluida uji. Hasil analisisnya menyatakan bahwa kecepatan liquid, subcooling, sifat fluida dan geometri mikro chanels memiliki pengaruh yang signifikan dalam karakteristik heat transfer, performansi pendinginan, dan transisi pola aliran. Disamping itu kecepatan fluida dan subcooling tidak berpengaruh terhadap heat transfer pada daerah boiling nucleat fully develop. Sinta (2010) [8] melakukan penelitian dengan menggunakan celah sempit anulus yang dipanaskan dari dua sisi (double heating). Lebar celah yang digunakan $1 \mathrm{~mm}$ dan $2 \mathrm{~mm}$, temperatur awal batang panas divariasikan dari $650^{\circ} \mathrm{C}, 750^{\circ} \mathrm{C}$, dan $850^{\circ} \mathrm{C}$. Fluida pendingin yang digunakan adalah air dengan temperatur $99^{\circ} \mathrm{C}$. Dari penelitian tersebut dapat diketahui bahwa semakin besar ukuran celah, maka semakin pendek waktu pembasahan ulangnya, sehingga kecepatan pembasahan ulangnya semakin tinggi disamping itu semakin tinggi temperatur awalnya, maka waktu pembasahan ulangnya semakin lama dan analisis fluks kalornya mengikuti pola pendidihan kolam.

Penelitian-penelitian tersebut memperjelas bahwa berbagai parameter yang mempengaruhi proses perpindahan kalor dalam celah sempit seperti fluida uji, ukuran celah, panjang plat yang dipanaskan (heated length), serta sebagian besar penelitian tersebut dilakukan dalam kasus pemanasan dari satu sisi (single heating). Dengan demikian penelitian untuk mengetahui pengaruh temperatur awal plat pemanas vertikal terhadap karakteristik boiling heat transfer dalam celah sempit kususnya dalam kasus double heating masih memungkinkan untuk dilakukan, sehingga pada akhirnya didapat waktu rewetting, pola rewetting, heat fluks, dan koefisien heat transfernya, yang merupakan penjabaran dari karakteristik boiling heat transfer.

\section{TEORI}

\section{Perhitungan Fluks Kalor}

Fluks kalor adalah laju kalor yang ditransfer persatuan luas. Berdasarkan pengertian dari fluks kalor, maka besarnya fluks kalor pada kurva pendidihan menjadi:

$q=\rho \cdot d \cdot c \cdot \frac{d T}{d t}$

\section{Korelasi Pembanding}

Korelasi pembanding dari penelitian terdahulu dilakukan berdasarkan regim pendidihannya yaitu: 
Untuk didih film digunakan korelasi yang didapat oleh Bromley (1950) [1]:

$q=C\left[\frac{k_{g}^{3} \cdot g \cdot \rho_{g}\left(\rho_{f}-\rho_{g}\right) \Delta h_{f g}}{\mu_{g} \cdot L_{\varepsilon}}\right]^{0,25} \times \Delta T_{s}^{0,75}$

$C=0,667-0,943$

$L_{h}<2 \pi\left[\frac{\sigma}{g\left(\rho_{f}-\rho_{g}\right)}\right]^{0,5} \rightarrow L_{\varepsilon}=L_{h}$

$L_{h}>2 \pi\left[\frac{\sigma}{g\left(\rho_{f}-\rho_{g}\right)}\right]^{0,5} \rightarrow L_{\varepsilon}=2 \pi\left[\frac{\sigma}{g\left(\rho_{f}-\rho_{g}\right)}\right]^{0,5}$

Korelasi Uap Laminer [3]:

$q=N_{u} \cdot\left(\frac{k_{g}}{D_{h}}\right) \Delta T_{s}$

Untuk regim didih transisi dan didih inti digunakan korelasi yang didapat oleh Murase, dkk (2001) [6] yaitu:

Untuk didih inti air panas lanjut rendah:

$q=1,1 \times \frac{k_{f}^{1,3}}{L_{\varepsilon}^{0,68}} \times\left[\rho_{g} \cdot \Delta h_{f g} \cdot v_{f}\right]^{-0,3} \times\left(\frac{P}{\sigma}\right)^{0,32} \times \Delta T_{s}^{1,3}$

Untuk didih inti air panas lanjut tinggi:

$q=2,2 \times \frac{k_{f}^{0,9}}{L_{\varepsilon}^{0,68}} \times\left[\rho_{g} \cdot \Delta h_{f g} \cdot v_{f}\right]^{0,1} \times\left(\frac{P}{\sigma}\right)^{0,32} \times \Delta T_{s}^{0,9}$

Untuk didih transisi:

$q=1,2.10^{14} \times \frac{\left[\rho_{g} \cdot \Delta h_{f g} \cdot v_{f}\right]^{5,5}}{k_{f}^{4,5} L_{\varepsilon}{ }^{0,68}} \times\left(\frac{P}{\sigma}\right)^{0,32} \times \Delta T_{s}^{-4,5}$

Untuk Critical Heat Flux (CHF) dan Leidenfrost point

Korelasi yang digunakan sebagai pembanding pada kondisi CHF yaitu:

Korelasi Monde, dkk (1982) [5]:

$q_{C H F}=\frac{(0,16) h_{f g}\left[\frac{\sigma g \Delta \rho}{\rho_{g}^{2}}\right]^{0,25}}{1+6,7 \times 10^{-4}\left(\frac{\rho_{l}}{\rho_{g}}\right)^{0,6}\left(\frac{L_{h}}{\delta}\right)}$

Korelasi Xia, dkk (1996) [10]:

$q_{C H F}=\frac{\Delta h_{f g}\left[\sigma g\left(\rho_{l}-\rho_{l}\right) \rho_{g}^{2}\right]^{0,25}}{4,59+0,11\left(\frac{L_{h}}{\delta}\right)}$ 
ISSN: 1411-4348

Korelasi Zuber (1958) [4]:

$\dot{q}_{\min }=0,09 \cdot \rho_{f} \cdot h_{f g}\left[\frac{\sigma \cdot g \cdot\left(\rho_{f}-\rho_{g}\right)}{\left(\rho_{f}+\rho_{g}\right)^{2}}\right]^{1 / 4}$

\section{PERALATAN DAN PROSEDUR EKSPERIMEN}

\section{Peralatan eksperimen}

Penelitian ini menggabungkan 2 rangkaian fasilitas yaitu Untai Uji Beta dan HeaTiNG-02 . Untai Uji Beta adalah alat untuk mengatur debit dan temperatur air yang mengalir kedalam celah. Untai Uji Beta memiliki pompa sentrifugal yang frekuensi putarnya dapat diatur untuk sirkulasi air pendingin, flow meter untuk mengukur laju aliran air pendingin, preheater untuk memanaskan air, termokopel dan beberapa katup untuk menutup dan mengalirkan air pendingin. HeaTiNG-02 merupakan seksi uji yang didalamnya terdapat plat utama dan plat penutup, jarak antara plat utama dan plat penutup ditetapkan $1 \mathrm{~mm}$. Pada plat utama terpasang 3 buah termokopel tipe-K yaitu TC-2B, TC-6B, TC-9B, dan pada plat penutup terpasang 3 termokopel dengan tipe yang sama (TC-2D, TC-6D, TC-9D) untuk mengukur perubahan temperatur yang terjadi selama proses pemanasan dan pendinginan. Gambar 2 memperlihatkan skema rangkaian alatnya.

Data akuisisi sistem jenis WinDAQ T1000 yang memiliki 24 kanal digunakan untuk merekam perubahan temperatur plat selama pengujian, dengan laju perekaman 1 data per detik. Slide regulator dengan daya maksimal $25 \mathrm{~kW}$ digunakan untuk mengatur masukan daya selama pemanasan berlangsung sampai temperatur plat yang direncanakan (seperti pada Tabel 1). Daya dinaikkan perlahan-lahan agar kalor terdistribusi merata.

\section{Prosedur eksperimen}

Eksperimen diawali dengan mengatur lebar celah yaitu $1 \mathrm{~mm}$, kemudian memanaskan plat utama dan plat penutup dengan keramik heater sampai temperatur awal plat yang direncanakan yaitu $500^{\circ} \mathrm{C}, 550^{\circ} \mathrm{C}$, dan $600^{\circ} \mathrm{C}$. Setelah temperatur awal tercapai, selanjutnya keramik heater dimatikan, dan air pendingin yang debit dan temperaturnya telah diseting sebesar $0,09 \mathrm{lt} /$ detik dan $90^{\circ} \mathrm{C}$ dialirkan kedalam celah. Pengambilan data temperatur tetap dilakukan sampai seluruh termokopel pada plat utama mendekati $90^{\circ} \mathrm{C}$.

Tabel 1. Parameter Penelitian

\begin{tabular}{lccc}
\hline \multicolumn{1}{c}{ Parameter } & \multicolumn{3}{c}{ Nilai } \\
\cline { 2 - 4 } & I & II & III \\
\hline Temperatur awal plat utama $\left({ }^{\circ} \mathrm{C}\right)$ & 500 & 550 & 600 \\
Tekanan $($ atm $)$ & & 1 & \\
Ukuran celah $(\mathrm{mm})$ & & 01,00 & \\
Debit air pendingin $(\mathrm{L} / \mathrm{s})$ & & 00,09 & \\
Temperatur air $\left({ }^{\circ} \mathrm{C}\right)$ & & 90,00 & \\
\hline
\end{tabular}



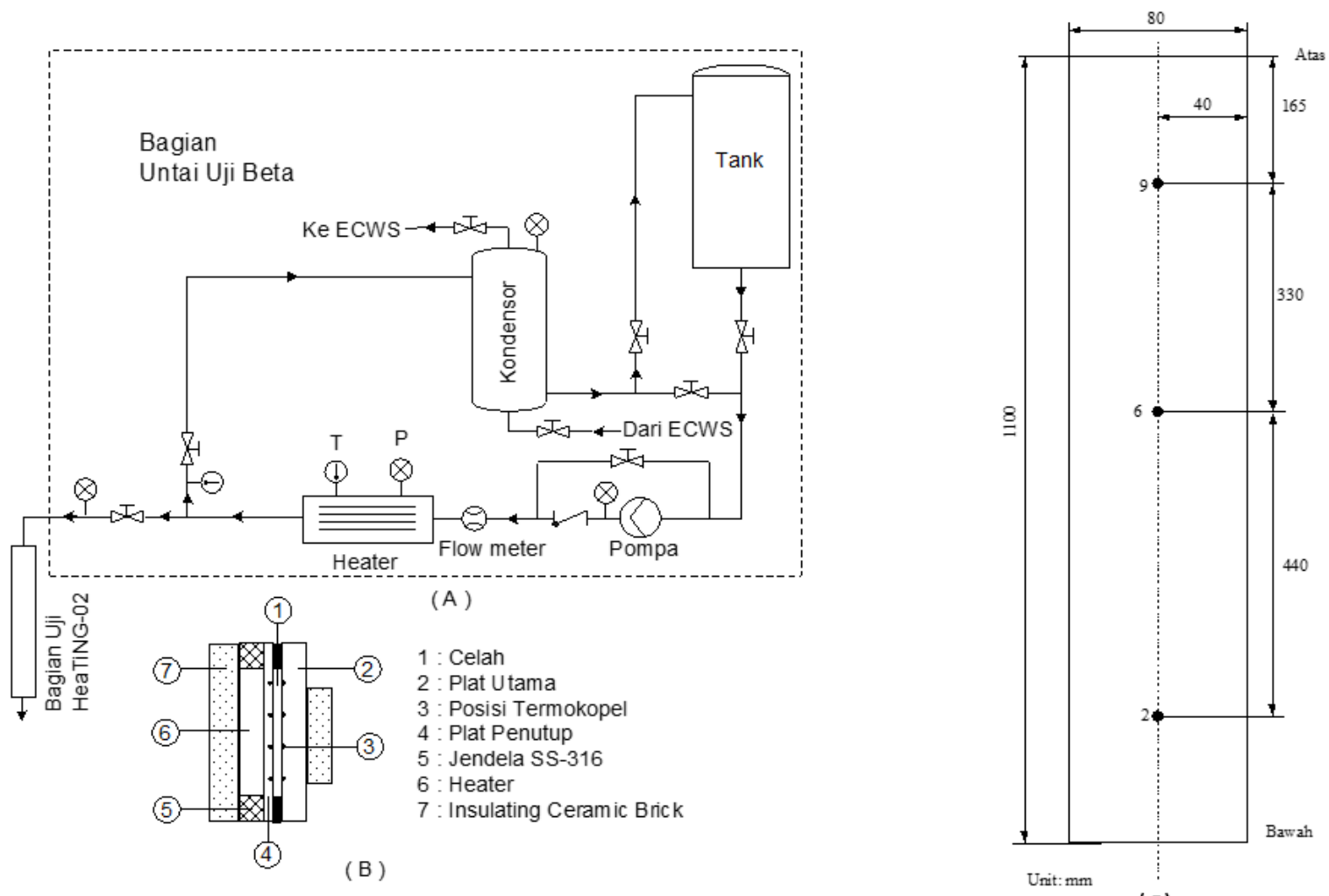

(C)

Gambar 2. (A) Skema alat penelitian, (B) Detail bagian Uji HeaTiNG-02,

(C) Penempatan termokopel

\section{HASIL DAN PEMBAHASAN \\ Transien Temperatur}

Transien temperatur merupakan perubahan temperatur yang diukur oleh termokopel selama selang waktu tertentu. Transien temperatur merupakan sejarah temperatur dari awal sampai akhir peroses pendingin. Disaat awal, temperatur plat utama maupun plat penutup cenderung mengalami penurunan yang cukup signifikan, selanjutnya setelah temperatur dibawah $100^{\circ} \mathrm{C}$ menurun secara perlahan-lahan sampai keseluruhan posisi termokopel mendekati temperatur $90^{\circ} \mathrm{C}$, yang merupakan akhir dari proses pengambilan data. Hal ini dikarenakan oleh disaat awal belum terjadi keseimbangn heat transfer, dalam artian bahwa air pendingin belum kontak dengan plat karena tekanan uap yang menyelimuti plat cukup tinggi. Selanjutnya, seiring dengan meningkatnya waktu, maka perbedaan temperaturnya tidak terlalu signifikan sehingga penurunan temperaturnya tidak terlalu drastis. 


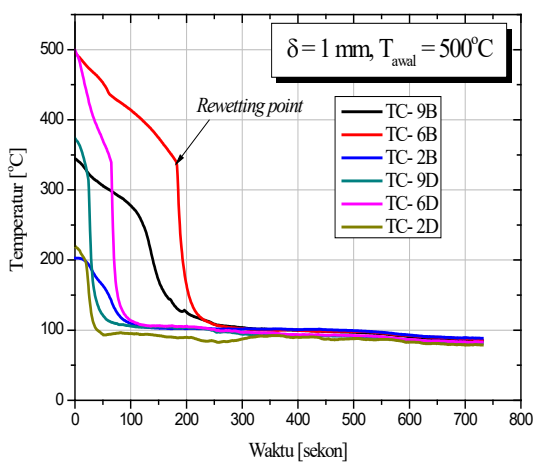

Gambar 3. Transien temperatur awal plat utama $500^{\circ} \mathrm{C}$

\section{Waktu rewetting}

Rewetting merupakan suatu kondisi ketika air mulai menyentuh permukaan plat. Rewetting poin diindikasikan dengan penurunan temperatur yang cukup drastis. Waktu rewettingnya dapat diketahui dari grafik transien temperatur. Untuk keseluruhan variasi temperatur awal plat, waktu rewetting tertinggi sebesar 290 sekon pada TC-6B, dan terendah sebesar 30 sekon pada TC-2D. Waktu rewetting plat penutup lebih cepat dari plat utama (seperti pada Gambar 3), hal ini mengindikasikan bahwa air pendingin terlebih dahulu menyentuh permukaan plat penutup, selanjutnya air pendingin menyentuh permukaan plat utama. Kejadian ini diprediksi terjadi karena tekanan uap pada permukaan plat utama lebih besar dari tekanan uap pada permukaan plat penutup. Tekanan uap yang lebih besar karena kalor yang ditransfer dari plat utama lebih besar, heat transfer yang besar dikarenakan oleh massa dari plat utama yang lebih besar dari plat penutup. Semakin tinggi temperatur awal plat, maka waktu rewettingnya semakin lama. Hal ini dikarenakan oleh semakin tinggi temperatur, maka tekanan uap yang menyelimuti permukaan plat semakin besar sehingga semakin lama waktu yang dibutuhkan air pendingin untuk kontak dengan permukaan plat.

\section{Pola rewetting}

Berdasarkan waktu rewettingnya dapat diketahui pola rewetting yang terjadi didalam celah. Pola rewetting dari eksperimen pada lebar celah $1 \mathrm{~mm}$, bahwa air pendingin awalnya menyentuh permukaan plat penutup sebelum menyentuh permukaan plat utama, hal ini dikarenakan oleh ketika terjadi proses pendinginan temperatur plat penutup lebih cepat mengalami penurunan, sehingga tekanan uap yang menyelimuti permukaan plat penutup lebih kecil dari tekanan uap pada permukaan plat utama. Penurunan tekanan yang lebih cepat ini dikarenakan oleh plat penutup yang kontak langsung dengan udara sekitar, sehingga terjadi pendinginan dari dua sisi.

Pola rewetting dalam celah pada permukaan plat penutup dan plat utama dapat dijelaskan bahwa air pendingin mulai menyentuh permukaan plat dari permukaan plat bagian bawah ke atas, dan terakhir di permukaan plat bagian tengah, hal ini dikarenakan permukaan plat bagian tengah memiliki temperatur yang paling tinggi sehingga air pendingin butuh waktu yang lebih lama untuk kontak dengan permukaan plat yang terselimuti oleh uap dengan tekanan yang cukup besar. Pola rewetting pada semua variasi temperatur awal plat utama tidak mengalami perbedaan sehingga perubahan temperatur awal plat tidak mempengaruhi pola rewetting. 


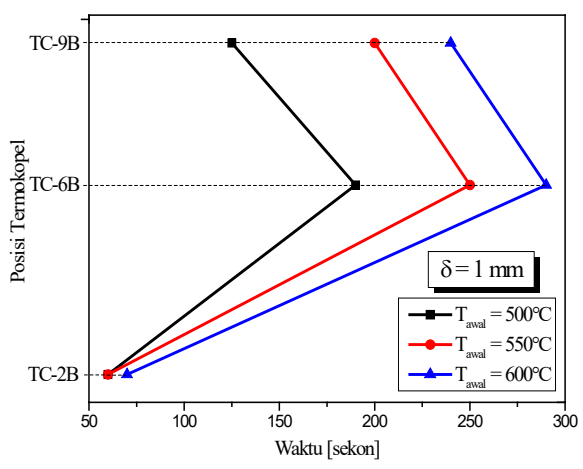

Gambar 4. Posisi termokopel vs waktu rewetting pada plat utama (TC-B)

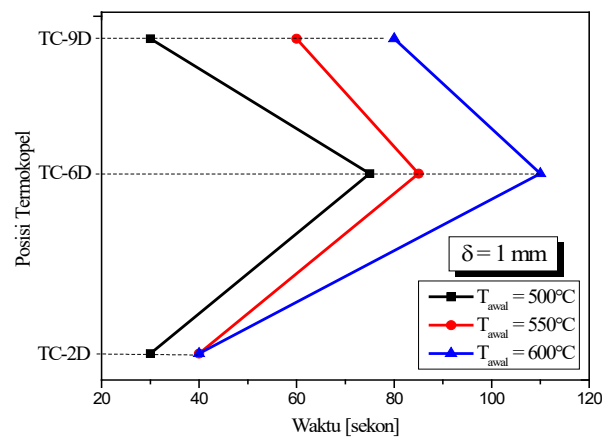

Gambar 5. Posisi termokopel vs waktu rewetting pada plat penutup (TC-D)

\section{Heat Flux}

Heat Flux dihitung berdasarkan persamaan 1 dengan menggunakan transien temperatur. Dari kurva pendidihan dapat diketahui bahwa sudah terbentuk didih film, didih transisi, dan didih inti. Didih film terjadi diawal proses, selanjutnya didi transisi kemudian didih inti dan diakhiri dengan konveksi alami. Saat terjadi didih film, fluks kalor yang dilepas permukaan plat utama sangat kecil, hal ini dikarenakan oleh adanya uap yang menutupi permukaan plat utama, sehingga menghalangi terjadinya kontak antara air pendingin dengan permukaan plat utama, pada kasus ini perpindahan kalor secara radiasi dari permukaan uap sangat dominan, hampir perpindahan kalor konduksi dan konveksi tidak terjadi.

Selanjutnya terjadi peningkatan fluks kalor yang ditransfer ke air pendingin, karena pada kondisi ini sudah mulai terjadi kontak antara air pendingin dengan permukaan plat sehingga perpindahan kalor tidak lagi didominasi oleh perpindahan kalor secara radiasi melainkan perpindahan kalor secara konveksi. Fluks kalor terus mengalami peningkatan dari kondisi minimum (Leidenfrost point) sampai kondisi kritis/Critical Heat Flux (CHF). Hal ini dikarenakan oleh semakin banyaknya air pendingin yang kontak dengan permukaan plat

Setelah mencapai kondisi CHF, fluks kalor mengalami penurunan, fenomena ini terjadi karena semakin menurunnya perbedaan temperatur permukaan plat dengan temperatur air pendingin, atau dengan kata lain bahwa $\Delta \mathrm{T}_{\text {excess }}$ semakin berkurang sehingga kalor yang ditransfer persatuan luas permukaan semakin kecil. Selanjutnya diakhiri dengan 
perpindahan kalor secara konveksi dan pada kondisi ini fluida yang mengalir didominasi oleh air pendingin, sehingga hanya terdapat fluida dalam bentuk satu fasa.

Berdasarkan kurva pendidihan dapat diketahui bahwa didih film terjadi ketika temperatur excess lebih dari $200^{\circ} \mathrm{C}$. Pada daerah didih film, dapat diketahui bahwa semakin rendah temperatur awal plat utama, maka fluks kalornya semakin rendah, karena belum terjadi kontak antara air pendingin dengan plat sehingga koefisien heat transfernya semakin rendah. Pada daerah transisi, untuk plat penutup semakin rendah temperatur awal plat utama, maka semakin tinggi $\Delta \mathrm{T}_{\text {excess }}$, hal ini dikarenakan oleh ketika temperatur semakin rendah maka semakin mudah air pendingin kontak dengan permukaan plat, sehingga semakin cepat untuk mencapai kondisi didih transisi. Pada daerah didih inti dapat diketahui, bahwa semakin tinggi temperatur awal plat utama, maka tidak mengalami kecenderungan yang berbeda dalam artian bahwa nilai heat fluksnya tidak mengalami perbedaan. Untuk plat penutup (termokopel D/ TC-D), pada kondisi Leidenfrost/Minimum Film Boiling (MFB) semakin tinggi temperatur awal plat utama maka semakin rendah heat fluks dan temperatur Leidenfrostnya, ini berarti bahwa ketika temperatur plat utama semakin tinggi, maka semakin rendah temperatur yang dibutuhkan untuk memulai transisi dari didih film. Ketika fluks kalornya semakin tinggi maka temperatur Leidenfrostnya semakin tinggi.

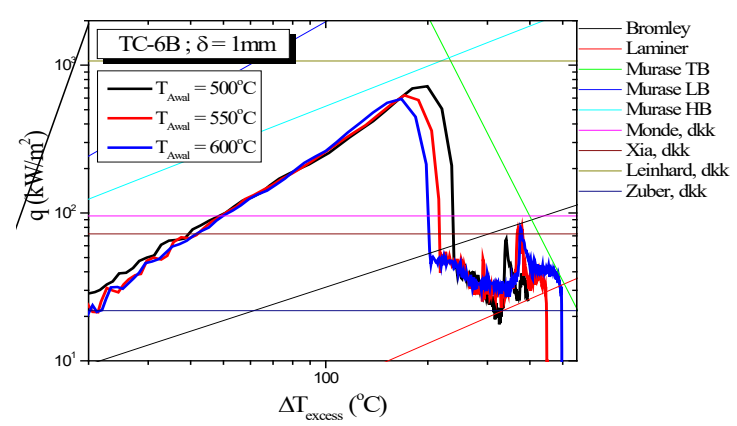

Gambar 6. Kurva pendidihan pada TC-6B untuk 3 variasi temperatur awal

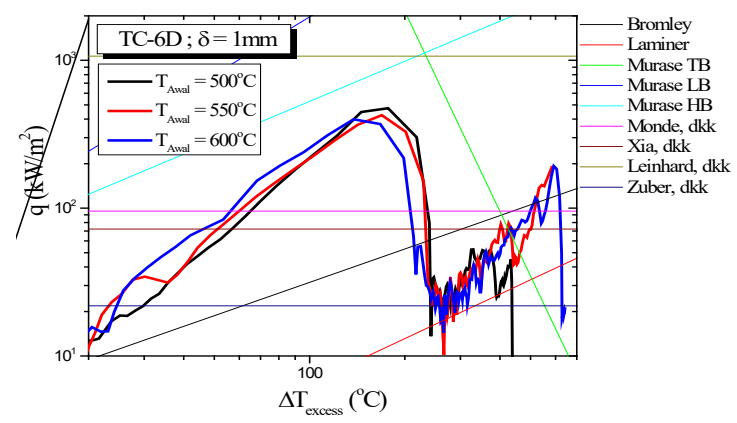

Gambar 7. Kurva pendidihan pada TC-6D untuk 3 variasi temperatur awal

\section{Critical Heat Flux (CHF)}

Sesuai dengan kurva pendidihan dapat diketahui bahwa untuk keseluruhan varisai temperatur awal plat utama, nilai CHF tertinggi sebesar $750 \mathrm{~kW} / \mathrm{m}^{2}$ saat temperatur awal $500^{\circ} \mathrm{C}$ dan terendah sebesar $400 \mathrm{~kW} / \mathrm{m}^{2}$ saat temperatur awal $600^{\circ} \mathrm{C}$. Berdasarkan perbedaan temperatur awal plat dapat dijelaskan bahwa semakin kecil temperatur awal plat, maka nilai CHF-nya semakin besar, ini disebabkan oleh ketika terjadi pendinginan, semakin kecil 
temperatur awal plat maka semakin besar perubahan temperatur ketika air pendingin kontak dengan plat. Perubahan temperatur yang besar mengakibatkan fluks kalor yang dihasilkan semakin besar.

\section{Perbandingan dengan peneliti lain}

Berdasarkan kurva pendidihan untuk ukuran celah $1 \mathrm{~mm}$ pada berbagai temperatur awal plat, dapat dianalisis bahwa pada daerah film boiling sebagian besar mendekati korelasi uap laminer dengan $\mathrm{Nu}=5,16$. Ini mengindikasikan bahwa pergerakan uap secara laminer ketika terjadi film boiling, dan korelasi Bromley (1950) [1] tidak cocok diterapkan dalam kasus ini, karena tidak mendekati hasil eksperimen ini. Dengan demikian korelasi pool boiling tidak cocok diterapkan untuk kasus flow boiling pada daerah didih film. Untuk posisi Leidenfrost point, sebagian besar mendekati korelasi Zuber (1958) [4], terutama saat temperatur awal $500^{\circ} \mathrm{C}$, sehingga korelasi ini dapat digunakan untuk memprediksi besarnya Minimum Heat Flux (MHF) dalam kasus flow boiling. Untuk daerah transisi lebih mendekati korelasi Murase, dkk (2001) [6]. Untuk daerah didih inti lebih mendekati korelasi Murase, dkk (2001) [6] untuk boiling superheat. Nilai CHF lebih mendekati korelasi Leinhard, dkk (2002) [4] dan sangat jauh dengan korelasi Xia, dkk (1996) [10] yang dilakukan pada kasus pool boiling dalam geometri plat, dengan demikian walaupun geometrinya sama, aliran fluida pendingin sangat mempengaruhi besarnya CHF. Jadi, semakin rendah temperatur awalnya, maka semakin mendekati korelasi Leinhard (2001) [4], dan Murase (2001) [6], baik untuk daerah didih transisi maupun didih inti superheat.

\section{KESIMPULAN}

Berdasarkan hasil analisis pengaruh perubahan temperatur awal plat utama terhadap karakteristik pendidihan yang meliputi waktu rewetting, pola rewetting, dan CHF dapat disimpulkan bahwa:

Waktu rewetting terendah sebesar 30 sekon dan tertinggi sebesar 290 sekon

CHF tertinggi sebesar $750 \mathrm{~kW} / \mathrm{m}^{2}$ dan terendah sebesar $400 \mathrm{~kW} / \mathrm{m}^{2}$.

Semakin tinggi temperatur awal plat, maka semakin lama waktu rewettingnya.

Perubahan temperatur awal plat utama tidak mempengaruhi pola rewetting.

Semakin tinggi temperatur awal plat, maka nilai CHF semakin rendah.

Untuk perbandingan dengan peneliti lain bahwa:

1. Daerah didih film tidak sesuai dengan kasus pool boiling.

2. Pada daerah transisi, semakin rendah temperatur awal plat, maka semakin mendekati korelasi Murase (2001) [6].

3. Nilai CHF mendekati korelasi Leinhard. dkk (2002) [4].

4. Titik Leidenfrost sesuai dengan korelasi Zuber (1958) [4].

5. Daerah didih inti mendekati korelasi Murase (2001) [6] untuk superheat vapor.

\section{Ucapan Terimakasih}

Terimakasih kepada Bapak Mulya Juarsa, S.Si., MESc., Bapak Ismu Handoyo dan Bapak Kiswanta, yang telah membantu selama eksperimen di Lab. Termohidrolika, PTRKN, BATAN Serpong.

\section{DAFTAR PUSTAKA}

[1] Bromley, L.A., 1950, Heat Transfer in Stable Film Boiling, Chemical Engineering Program, Vol.46, pp.221.

[2] Chang, H.OH., and Stan, B.E., 1993, Critical Heat Flux for Low Flow Boiling in 
Vertical Uniformly Heated Thin Rectangular Channels, International Journal Heat Mass Transfer, Vol. 36, No. 2, pp. 325-335.

[3] Juarsa, M., dan Antariksawan, A.R., 2007, Efek Batasan Counter Current Flow Pada Perpindahan Panas Pendidihan Dalam Celah Sempit, Jurnal Teknologi Reaktor Nuklir Tri Dasa Mega, Volume 10 No 1.

[4] Lienhard, J.H., and Dhir, 2002, A Heat Transfer Textbook, Third edition, Phlogiston press.

[5] Monde. M., Kusuda, H., and Uehara, H., 1982, Critical Heat Flux during Natural Convective Boiling in Vertical Rectangular Channel Submerged in Saturated Liquid, Trans. ASME, Vol.104, p.300-303.

[6] Murase, M., Kohriyama, T., Kawabe, Y., Yoshida, Y and Okano, Y., 2001, Heat Transfer Models in Narrow Gap, Proceedings of ICONE 9, Nice (France), 8 - 12 April.

[7] Peng, X.F., and Wang, B.X., 1998, Boiling Nucleation During Liquid Flow in Microchannels, International Journal of Heat and Mass Transfer, Vol. 41, No. 1, pp. 101-106.

[8] Sinta, T.H., 2010, Studi Eksperimental Perpindahan Kalor Pendidihan pada Celah Sempit Anulus dengan Variasi Lebar Celah dan Temperatur Awal Berbasis pasa Kasus Double Heating, Tesis, Universitas Gadjah Mada.

[9] Sudo, Y., and Kaminaga, M., 1989, A CHF Characteristic for Downward flow in A Narrow Vertical Rectangular Channel Heated From Both Sides, International Journal Multiphase Flow, Vol. 15, No. 5, pp. 755-766.

[10]Xia, C., Weilin, H., Zengyuan, G., 1996, Natural Convective Boiling in Vertical Rectangular Narrow Channals, Experimental Thermal and Fluid Science, Vol.12, p.313-324 